\title{
THE UNITED STATES AS THE GUARANTOR OF THE SECURITY FOR THE REPUBLIC OF KOREA
}

The purpose of this study is introducing the role and importance of the United States in ensuring the safety of South Korea. To understand better the U.S. protection guarantees for the Republic of Korea, the author has focused on the political and legal aspects of these guarantees presented in the ROK-U.S. Mutual Defense Treaty. The other legal documents are also mentioned, documents that allow for the U.S. military presence in South Korea. The different types of the U.S. troops, which have been deployed in the Republic of Korea are well described and various manifestations of the ROK-U.S. military cooperation, are also included, as well as further prospects of the evolution of the American South Korean military alliance.

The United States were strongly interested in the Korean Peninsula during the World War II. At that time, the United States Department of State had begun to recognize Korea as a quite important area on the political map of the world. ${ }^{1}$ It was highly noticeable, especially at the time of the landing of the Soviet troops in Korea. As a result, the United States was forced to occupy the south part of Korea, including the capital in Seoul, and also to improvise the formula of the trusteeship on the Korean Peninsula, ${ }^{2}$ which - in the final settlement - ended the division of the peninsula into two Korean states, and later - after the withdrawal of the American and Soviet troops from that peninsula - the civil war in the years 1950-1953. The one of the results of the Korean War was signing the ROK-U.S. Mutual Defense Treaty between The U.S. and South Korea on October 1, 1953, and on the basis of this treaty - the establishing of the U.S. military forces bases on the territory of the Republic of Korea.

The military alliance concluded in 1953 between the USA and South Korea is one of the strongest alliances in this part of the world. The basis for the establishment of this alliance was mentioned before fixing the ROK-U.S. Mutual Defense Treaty, under which the United States and the Republic of Korea have committed to provide the assistance as a result of an armed attack. In this way, the USA has become the guarantor of the security and defense for South Korea, especially the defense against an attack from the DPRK.

1 A. Bober, Korea Poludniowa i USA, matżeństwo z rozsqdku, czy chwilowe zauroczenie?, "Kurier Dyplomatyczny" 2010, No. 2, http://www.kurier.diplomacy.pl/site/korea-poludniowa-i-usa--malzenstwo-zrozsadku--czy-chwilowe-zauroczenie (3.04.2011).

${ }^{2}$ A country Study: South Korea - World War II and Korea, http://lcweb2.loc.gov/cgibin/ query/r?frd/cstdy:@field\%28DOCID+kr0022\%29 (5.04.2011). 


\section{THE MUTUAL DEFENSE TREATY BETWEEN THE UNITED STATES AND THE REPUBLIC OF KOREA}

The alliance between the United States and the Republic of Korea that has been lasting almost sixty years has led to the signing a large number of formal agreements between those two states. Those treaties include the ROK-U.S. Mutual Defense Treaty signed in 1953, and also the U.S.-ROK Status of Forces Agreement, in short: SOFA, from 1966, 1991 and 2001. Except that, the USA and South Korea also signed a large number of other documents related to solving many different problems from the domain of security, and attempts of solving those problems were taken on the Summits such as The Security Consultative Meeting (SCM), The Korea-U.S. Military Committee Meeting (MCM) or The Future of the Alliance Policy Initiative (FOTA). ${ }^{3}$

The foundation for the military alliance between the USA and South Korea, which is still the support of the security and national strategy for the Republic of Korea, was the signing of the armistice ending the Korean War. That armistice was also the basis for the development of the democracy and prosperity in the Republic of Korea. ${ }^{4}$ Shortly after the signing of the armistice the negotiations began; those negotiations aim was achieving the treaty for the defense and security not only in South Korea, but also all around the Korean Peninsula. The signing of such a document was an intention of the South Korean government.

Despite the fact, that the United States did not agreed to the proposals of Rhee Syngman (president of South Korea) on the individual records in the treaty, especially those connected with extending territorial boundaries of South Korea and the conclusion of that agreement for indefinite duration, ${ }^{5}$ in two months after the end of the hostilities on the Korean Peninsula - the ROK-U.S. Mutual Defense Treaty between South Korea and the USA was signed on October 1, 1953. This document was signed - for the USA - by John F. Dulles, the Secretary of State and for the Republic of Korea - by Pyun Yung Tai, the Minister of Foreign Affairs. ${ }^{6}$

Like any other similar treaty on the defense signed by the United States after the World War II, the ROK-U.S. Mutual Defense Treaty between the Republic of Korea and the USA consists of a preamble and six articles. The records of those articles relate primarily to using appropriate methods and means aimed at deterring the possible external armed aggression on the signatories of that treaty, measures needed to solve international disputes; treaty also contains provisions on the other administrative issues. ${ }^{7}$

3 S. K. Kwang, The United States-ROK alliance, 1953-2004: Alliance institutionalization, Southern Illinois University at Carbondale 2006, p. 47.

${ }_{4}$ The ROK-US Mutual Defense Treaty: Background to the signing of the Mutual Defense Treaty, http://www.koreaembassy.org/bilateral/military/eng_military4.asp (30.08.2011).

5 Ch. J. Lee, A troubled peace: U.S. policy and the two Koreas, The Johns Hopkins University Press, Maryland 2006, p. 38.

${ }^{6}$ S. K. Kwang, The United States-ROK alliance, op. cit., p. 75.

7 E. Y. J. Lee, Establishment of a de jure peace on the Korean Peninsula: inter-Korean peace treaty-making under international law, "Asian Yearbook of International Law" 1998-1999, Vol. 8, (eds.) B. S. Chimni, S. S. Ko, M. Miyoshi, M. C. W. Pinto, S. P. Subedi, Leiden 2003, pp. 97-98. 
The article 3 of the Treaty which was negotiated in Seoul, and signed in Washington D.C., between South Korea and the United States, specifies that if an attack will occur on either party to this treaty or the territories belonging to the signatories would be threatened, that each party would take the action to counter this threat. ${ }^{8}$ However, in accordance with the provisions of next article of the ROK-U.S. Mutual Defense Treaty, South Korea allows the United States to create U.S. military bases in the Republic of Korea. ${ }^{9}$

The U.S. Senate ratified the ROK-U.S. Mutual Defense Treaty on January 26, 1954. However, during the ratification process, U.S. Senators added to this treaty the "additional written agreement", stating that the United States is not obliged to assist the Republic of Korea, unless this assistance is needed to repel the external armed attack on South Korea. The addition of that provision by the U.S. Senate was the result of the careful and deliberate conduct of the American parliament, because the acceptance of the ROK-U.S. Mutual Defense Treaty in the form proposed by Rhee Syngman could be a factor leading to the commencement of the South Korean offensive against North Korea. The Republic of Korea agreed to that provision and three days after the U.S. ratification - on January 29, 1954, also ratified the treaty. The entry of this treaty in the force was possible only after the exchanging ratified documents by both countries; therefore, the official exchange of those documents was scheduled for May $18,1954 .{ }^{10}$ But the exchange took place on November 17, 1954. ${ }^{11}$

The ROK-U.S. Mutual Defense Treaty was, and still is the guarantee of the national security for the Republic of Korea. This U.S.-South Korean alliance in the security is one of the most important alliances concluded so far by the United States. ${ }^{12}$ The purpose of that agreement has been a promise of the cooperation between the USA and South Korea in case of the security threats in this part of the world, no matter what type that threat would be taken. ${ }^{13}$ Currently, the treaty not only serves to prevent to another North Korean attack on its southern neighbor, but also provides a continental base point for the U.S. forces in the face of the close proximity of China and Russia.

This treaty as well provides first line of defense for Japan, ${ }^{14}$ and also supports the creation and functioning in South Korea permanent U.S. military bases, especially for the $2^{\text {nd }}$ Infantry Division, and as well for selected the U.S. Air Force units. ${ }^{15}$ The alliance between the United States and South Korea also ensures the expansion the number of the U.S. military forces in the Republic of Korea and makes as though the nuclear umbrella, which provides in this way - at low expenditure for military purposes - to im-

S. H. Lee, The Korean War, Pearson Education 2001, p. 111.

9 Ibidem.

${ }^{10}$ Ibidem, pp. 111-112.

11 S. K. Kwang, The United States-ROK alliance, op. cit., p. 73.

12 K. Oh, U.S.-ROK: The Forgotten Alliance, http://www.brookings.edu/opinions/2008/ 10_south_korea_oh.aspx (29.08.2011).

13 A. K. Brezina, U.S. Military presence in the Republic of Korea, "SPEA Honors Paper Series" 2008, Vol. 2, No. 3, http://www.indiana.edu/ spea/pubs/undergradhonors/ honors_vol.2_no.3.pdf (22.02.2012).

${ }_{15}$ K. Oh, U.S.-ROK: The Forgotten Alliance, op. cit.

15 A. K. Brezina, U.S. Military presence in the Republic of Korea, op. cit. 
plement economic policy that will lead to the rapid economic growth and development of South Korea. ${ }^{16}$

\section{THE AMERCIAN MILITARY PRESENCE IN SOUTH KOREA}

According to previously presented the ROK-U.S. Mutual Defense Treaty, the United States maintains in South Korea its troops, that are deployed in several bases distributed throughout the territory of the Republic of Korea. Therefore pursuant to the provisions of the Article IV of the ROK-U.S. Mutual Defense Treaty, the United States has been granted "[...] the right to dispose [...] land, air and sea forces in and about the territory" "17 of South Korea. The conditions, under which the U.S. military may use the "hospitality" of the Republic of Korea, have also been transcribed and regulated by the law, so the U.S. troops could remain without major obstacles in the territory of South Korea. These conditions are reagulated by law and agreements for the U.S. military presence in the Republic of Korea are based on the ROK-U.S. Mutual Defense Treaty, and especially mentioned earlier, before the Article IV of this Treaty.

Mentioned previously the U.S.-ROK Status of Forces Agreement, in short: SOFA, is just an agreement for the U.S. military presence in the Republic of Korea. It was signed in 1966, but over the years, it has been modified severely times. The latest version of SOFA comes from 2001; it takes into account the maturity of the Korean political and legal system. As a result, the newest version of SOFA involves the transfer of more rights, but also obligations on the authorities of South Korea. ${ }^{18}$ This agreement serves the common interests of South Korea and the United States; interests associated with the settlement of all the matters relating to the presence of the U.S. forces involved in the defense of South Korea. Thanks to this The Treaty, fundamental rights of the American citizens residing in the Republic of Korea are protected, however certain provisions of the U.S.-ROK SOFA are reserved. In the SOFA the rights and obligations for the U.S. Army during its service in South Korea are defined. They are also related to use the facilities and military sites. As well, the U.S.-ROK SOFA provides favorable living conditions for the U.S. military forces, they are necessary to ensure the basic quality of life. It could be said, that under the provisions of the U.S.-ROK SOFA it was included everything, which is related to the military and civilian personnel of the United States Forces Korea (USFK) and their families, from the moment of their entry into the Republic of Korea until their departure from South Korea. ${ }^{19}$

However, in addition to describing the principles of the stationing of the U.S. troops in South Korea, the U.S.-ROK SOFA was also the basis for the formation of the South Korean anti-American movement, which is seeking to transfer the anti-American senti-

16 K. Oh, U.S.-ROK: The Forgotten Alliance, op. cit.

17 R. Ch. Mason, Status of Forces Agreement (SOFA): What Is It, and How Has It Been Utilized?, January 2011, http://www.fas.org/sgp/crs/natsec/RL34531.pdf (19.09.2011), p. 12.

18 GI Myths: The Unfair US-Korea SOFA by GI Korea, http://rokdrop.com/2008/02/22/ gimyths-the-unfair-us-korea-sofa/ (19.09.2011).

19 US Military Facilities: Korea, http://www.globalsecurity.org/military/facility/koreaupdates.htm (19.09.2011). 
ment in all the South Korean society. ${ }^{20}$ Since the beginning of the U.S. military presence in the territory of South Korea, the citizens of the Republic of Korea have patiently looked at the U.S. Army that has been using the South Korean land. But there were many situations, in those South Koreans began to doubt the intentions of the American army stationed in their country. Although the incidents involving the U.S. soldiers are still occurring, the support for the U.S. Army in South Korea is noticeable in a wider area of the Republic of Korea. The increased anti-American sentiment throughout the country is observed from December 2002 when during the mission an American armored vehicle accidentally ran over two South Korean schoolgirls. ${ }^{21}$

The number and structures of American troops stationed in the territory of South Korea have changed over the years. During the Korean War, the U.S. military force consisted of eight combat divisions. But in 1955, despite the protests from the South Korean President, Rhee Syngman, President of the United States, Dwight Eisenhower, reduced the number of American troops in South Korea from eight divisions to only two. For Rhee Syngman the reduction of U.S. troops in the Republic of Korea was not favorable, because Rhee had planned to use the American military forces to attack on North Korea and in that way to lead to the unification of the two Korean states. Despite the South Korean objection, the reduction of American military presence in the Republic of Korea was made and in the years 1954-1971 the two American divisions, which were deployed in South Korea, counted an average of about 63 thousands of soldiers. ${ }^{22}$

The Vietnam War also had an influence on the number and structure of the stationed in South Korea U.S. troops. In 1969, U.S. President, Richard Nixon and his administration led to a revision of the U.S. policy towards Asia. The result of that revision was the creation of the Nixon Doctrine, under which the United States would keep its alliance obligations arising from treaties, while requiring of its allies to maintain their forces at a level, which could guarantee the allies to keep the safety by themselves. Therefore, as a result of the implementing the provisions of that doctrine, one of the American brigades stationed in South Korea was reduced by the 20 thousand soldiers. ${ }^{23}$

A further reduction of the U.S. military presence in the Republic of Korea occurred along the election of the new American president, Jimmy Carter. He reduced the number of American soldiers in South Korea in 3.4 thousand servicemen (the previously planned 6 thousand), what means that at that time there were deployed only 39.5 thousand soldiers from the U.S. Army in the Republic of Korea. The next U.S. President, Ronald Regan, changed the policy and increased the number of stationed American troops to 41 thousand. But his successor, George H. W. Bush, began the three-phase process of reducing the number of the U.S. troops in the Republic of Korea. However, only the first phase was implemented, another two have been suspended due to the growing

${ }^{20}$ GI Myths: The Unfair US-Korea, op. cit.

21 A. K. Brezina, U.S. Military presence in the Republic of Korea, op. cit., pp. 9-10.

22 T. Roehring, Restructuring the U.S. military presence in Korea: Implications for Korean security and the U.S.-ROK alliance, "Korea Economic Institute: Academic Paper Series", January 2007, Vol. 2, No. 1, http://www.keia.org/publication/restructuring-us-military-presence-korea-implicationskorean-security-and-us-rok-allianc (26.11.2011), p. 1.

${ }^{23}$ Ibidem, p. 2. 
nuclear threat from North Korea. The next U.S. president, Bill Clinton, maintained the hold of the withdrawal of the U.S. troops from South Korea. That meant that for the next decade the number of the American soldiers stationed in the bases in the Republic of Korea has remained at an average of 37.5 thousand of servicemen. ${ }^{24}$

The previous changes and the movement of the U.S. troops have aroused the controversy among the people in South Korea. According to the South Korean residents, the reorganization of the U.S. military presence in the Republic of Korea could lead to a greater audacity in the proceedings of North Korean authorities, and even to the wrong perception of the involvement of the United States in South Korea by the authorities in North Korea, and precisely - to perceive those actions as a decline in the U.S. willingness to defend the Republic of Korea against the invasion from its northern neighbor. ${ }^{25}$ The North Korean army is adapted to the classic South Korean-American military partnership through well suited to that the North Korean tactic and weapon systems, which allow the DPRK for the confrontation with the objectives in South Korea. That is why American politicians believe that the alliance between the United States and the Republic of Korea will strengthen peace in this part of the world, but - to provide and maintain the international peace and security - the U.S. troops must remain in South Korea. ${ }^{26}$

That situation causes that in the Republic of Korea are the United States Forces Korea (USFK), that is the land, air and maritime U.S. military deployed in South Korea. The main formations of the USFK are: the Eighth U.S. Army (EUSA), U.S. Air Forces Korea (Seventh Air Force, USAFK) and U.S. Naval Forces Korea (CNFK). The USFK comprises more than 85 active military bases and in those bases is employed approximately 37.5 thousand of the military personnel assigned to South Korea. ${ }^{27}$ During the meeting between the Minister of Defense of the Republic of Korea, Lee Sang Hee, and the U.S. Secretary of Defense, Richard M. Gates, in 2008 it has been established that the number of the American soldiers stationed in South Korea would remain on the level 28 and a half thousand soldiers. ${ }^{28}$

The main task of the Eight US Army (EUSA) is to support the troops of South Korea in deterring the DPRK from possible aggression against the Republic of Korea. Therefore, the EUSA provides military forces for the Commander in Chief of United Nations Command, the United States Forces Korea and the Republic of Korea/US Combined Forces Command. However, in the course of any military operation the main task of the Eight US Army is to take up the fight, to provide the combat support and the technical assistance in military operations according to the recommendations, as well to support

\footnotetext{
24 Ibidem.

25 R. Weitz, Why US needs South Korea base, http://the-diplomat.com/2011/08/21/why-usneeds-south-korea-base/ (20.02.2012).

26 Sgt M. J. Carden, U.S. presence necessary for Korean security, officials say, http://www.army.mil/ article/45317/us-presence-necessary-for-korean-security-officials-say/ (23.02.2012).

27 U.S. Forces, Korea / Combined Forces Command / Combined Ground Component Command $(G C C)$, http://www.globalsecurity.org/military/agency/dod/usfk.htm (29.08.2011).

28 Briefing by Defense Secretary Gates and ROK Minister Lee 17 October 2008, http://www.america.gov/st/texttrans-english/2008/October/20081020121847eaifas0.7119104.html (26.11.2011).
} 
the Combined Forces Command and Ground Component Command. ${ }^{29}$ The headquarter of the EUSA is localized in the Yongsan Garrison; however, by the year 2016 it will have been transferred to the Camp Humphrey and also there the EUSA will be functioning as the Second Infantry Division.

The American air forces stationed in the Republic of Korea are called the U.S. Air Forces Korea and are localized in two bases - Kunsan Air Base and Osan Air Base. The Osan Air Base is located 48 miles to south of the Korean De-militarized Zone; They are called Mustangs of the $51^{\text {st }}$ Fighter Wing, belonging to the most extended wing of the American aviation during the fighting actions. Moreover, that base includes also the headquarters of the U.S. Air Force. The main task of the soldiers stationed in the Osan Air Base is a maintaining the combat readiness, which plays the important role in providing the defense for South Korea and as well in maintaining the stability in the region of Northeast Asia. ${ }^{30}$ On the other hand, the Kunsan Air Base is located on the coast of the Yellow Sea (the South Korea's west coast). Nowadays the $8^{\text {th }}$ Fighter Regiment (the so called Wolf Pack) is located in that base, however the same base has been created already in 1938 by the Japanese. In 2002 the authorities in the United States and in South Korea agreed to the implementation of the Land Partnership Plan (LPP), which aims to lead to a radical change in the presence of the U.S. troops on the territory of the Republic of Korea. But those authorities also agreed that Kunsan Air Base is expected to remain under the U.S. control. ${ }^{31}$ There are over 2,900 people in that base, including soldiers, civilians, etc. The host of the Kunsan Air Base is the $8^{\text {th }}$ Fighter Wing, which is a part of the $7^{\text {th }}$ Air Force, stationed in the Osan Air Base (but the entire U.S. Air Forces stationed in South Korea are under the Pacific Air Forces, which are established in Hickam Air Force Base in Hawaii). ${ }^{32}$

The US Naval Forces Korea (also known as the Commander, US Naval Forces Korea / CFNK) is the representation of the U.S. Navy in South Korea. The main task of CFNK is to provide the leadership and to carry the expertise in the "sea matters" of the Republic of Korea. The aim of this task is the improvement of the institutional and operational effectiveness, and as well the effectiveness in the co-operation of the American and South Korean navy, and also to strengthen their efforts in improving the safety of South Korea and the entire region of the Northeast Asia. That is why the representatives of the CNFK work closely with their South Korean counterparts throughout the year. In addition, they co-ordinate the participation of the United States Navy in a large number of annual joint military exercises. The CNFK is located on the U.S. Army Garrison-Yongsan in Seoul. ${ }^{33}$

Writing about the American military presence in South Korea, it is worth to mention about the Combined Forces Command (CFC). CFC was established on November 7, 1978. The main task of the joint American-South Korean command is the prevention of

29 Eighth United States Army (EUSA), http://www.globalsecurity.org/military/agency/army/ 8army.htm (22.02.2012).

30 Osan Newcomers, http://www.osan.af.mil/newcomers/index.asp (23.02.2012).

31 Kunsan Air Base, http://www.globalsecurity.org/military/facility/kunsan.htm (23.02.2012).

32 Welcome - Kunsan Mission, http://www.kunsan.af.mil/main/welcome.asp (23.02.2012).

33 About Us, http://www.cnic.navy.mil/Korea/AboutUs/index.htm (23.02.2012). 
an aggression against South Korea, and ultimately the defeat the aggressor. To achieve that, the Combined Forces Command has an operational control over 600 thousand of the active military personnel (including the land, sea and air personnel) originating in both states. During the war, the CFC may have 3.5 million reservists from South Korea and the additional U.S. forces deployed outside the borders of the Republic of Korea. ${ }^{34}$

Since 2005, the character of the American presence in the Republic of Korea has been changing. Since that date the task of the U.S. troops stationed in South Korea is not only to defend the Republic of Korea against an armed aggression from North Korea, but also - and in the implementation of new policies known under the name Strategic flexibility - those troops can also be used outside of South Korea in case of the appearance of any circumstances, forcing the use of the U.S. troops, for example in the case of the Chinese invasion of Taiwan. ${ }^{35}$

\section{THE MILITARY COOPERATION BETWEEN THE USA AND SOUTH KOREA}

The first fifteen years of the military cooperation between the United States and the Republic of Korea, that is the years 1945-1960, led to the transformation (by the Americans) the South Korean troops from small, unorganized police in the most dominant institution in the Republic of Korea. The aim of the American training programs for the South Korean army was the creation of the effective forces supporting the United States in the Cold War rivalry, especially by instructing the South Korean officers how to perform the technically complex and logistical operations. Unfortunately, those plans also led to separate the elite of South Korean officers from the rest of the Korean society, and as well indoctrinated those officers by instilling a sense of duty and patriotism, which the later years led to the military dictatorships in South Korea. ${ }^{36}$

The Republic of Korea was entirely dependent on the U.S. military aid, and also on the U.S. supply of the equipment until the mid-sixties of the $20^{\text {th }}$ century. That situation changed in 1960, when the Nixon Doctrine was announced, which the main aim was the expansion of the armed forces and military capability of the American allies in the Asian part of the world. That doctrine, and as well the change of the concept of the U.S. administration's foreign policy resulted in the fact that the U.S. authorities decided to transfer to South Korea the amount of more than 1.5 billion dollars, which were dedicated - as an assistance program - to support the South Korean plan for the expansion of the armed forces; this plan covered the years 1971-1975. ${ }^{37}$

The one of the most noticeable examples of the military cooperation between the United States and the Republic of Korea are the annual joint military exercises con-

\footnotetext{
34 Combined Forces Command-Mission of ROK/US Combined Forces Command, http://www.usfk.mil/ usfk/content.combined.forces.command.46 (26.11.2011).

35 T. Crowell, A true Japan-Korea-U.S. Alliance, http://www.realclearworld.com/articles/2011/ 01/18/a_true_japan-korea-us_alliance_99357.html (29.02.2012).

36 G. Brazinsky, Nation building in South Korea: Koreans, Americans, and the making of a democracy, UNC Press Books 2007, p. 71.

37 O. Pietrewicz, Korea Poludniowa - coraz większa samodzielność, http://www.psz.p1/Oskar-Pietrewicz-Korea-Poludniowa-coraz-wieksza-samodzielnosa (16.09.2011).
} 
ducted by the armies of both countries. The South Korean-American Combined Forces Command conducts joint military maneuvres of the two countries in every year. The series of such exercises includes: Team Spirit, Ulchi Focus Lens (since 2008 known as Ulchi Freedom Guardian), Reception, Staging, Onward Movement and Integration (RSOI) and also Foal Eagle. ${ }^{38}$ The main aim of these exercises is the overview of the possibilities of the realization the operational plans by the combined forces of the United States and South Korea, and as well the strengthen the readiness of those forces to take action. As a part of those exercises is presented the permanent defensive posture of the South Korean-American combined forces, which is the strong signal for North Korea to give up its ambition and resolving disputes through military means and to turn them on the peaceful measures. ${ }^{39}$

The military exercise called the Team Spirit were originally designed by the United States and South Korea for the political and military purposes. The decision to merge the several smaller joint exercises conducted since 1969 and establishing in that way the consolidated and complex maneuvers (carried out on land in the spring of each year) was made during the annual meeting of the Security Consultative Meeting in 1975. The first exercises were conducted yet in 1976 - the United States tended to show North Korea a strong American commitment to the Republic of Korea. ${ }^{40}$ The joint exercises in that series of maneuvers were held each year, but in the year 1993 their conduct was stopped. The cancelation of those exercises was the result of the American and South Korean hopes for the abandonment by the DPRK the nuclear program and to make by the North Korean authorities the permission for the international inspections. Those maneuvers were also planned for the years 1994-1996, but that time as well the U.S. and South Korean authorities decided to resign from their conduct - that would be an incentive to improve mutual relations with North Korea. Overall, more than 200 thousand soldiers from both countries took part in the Team Spirit. ${ }^{41}$

The another group of the common South Korean-American maneuvers is the Ulchi Focus Lens/Ulchi Freedom Guardian. The name of these exercises comes from Ulchi Mundeok, an early Korean military leader who countered the Chinese invasion of the Sui Dynasty in the seventh century. ${ }^{42}$ Initially, those maneuvers were the two different exercises - the Focus Lens (that was created in 1954 by the United Nations Command) and the Ulchi (practiced by the authorities of the Republic of Korea after the discovery of armed North Korean agents in January 1968 in South Korea). In the year 1976 those two exercises were combined in one. The central and local authorities (above the set level), representatives of the major industries and soldiers with higher levels of ground,

${ }^{38}$ US Forces Korea - Exercises, http://www.globalsecurity.org/military/ops/ex-usfk.htm (20.09.2011).

39 Military Alliance - The ROK-US Combined Forces Command, http://www.koreaembassy.org/ bilateral/military/eng_military3.asp (26.02.2012).

40 J. F. Farrell, Team Spirit: A Case Study on the Value of Military Exercises as a Show of Force in the Aftermath of Combat Operations, "Air \& Space Power Journal", Fall 2009, http://www.airpower.au.af.mil/airchronicles/apj/apj09/fal09/farrell.htm (20.09.2011).

${ }^{41}$ US Forces Korea - Exercises, op. cit.

42 UNC/CFC/USFK Public Affairs Office, Exercise Ulchi Freedom Guardian 2011 begins, http://www.usfk.mil/usfk/press-release.exercise.ulchi.freedom.guardian.2011.begins.882 (20.09.2011). 
naval and air forces take part in those exercises. ${ }^{43}$ That is a simulation performed by the Combined Forces Command with the South Korean government. It takes place in late summer - in August and September. The main aim of those exercises is the practice, evaluation and improvement of emergency measures and procedures in the conjunction with the plans of war, serving the defense of the Republic of Korea. Those are the largest in the world exercises of the computerized headquarters and the control. Those tasks are focused on the fact how the forces of South Korea and the United States should defend the Republic of Korea against the attack from North Korea. Every year the DPRK criticizes those maneuvers, calling them the preparations for a war. ${ }^{44}$

On the other hand, the Reception, Staging, Onward Movement and Integration (RSOI) relies on the verification of the practical implementation of the procedures associated with the moving of the increased U.S. forces, and also the integration of those forces on the battlefield. Under those maneuvers the soldiers are as well practicing the military support from the South Korean forces, mutual logistics support, mobilization and restoration of the combat capability. The United States emphasized the need of ensuring the safe, fast and efficient implementation of activities improving the moving the large number of the American troops. That was a result of the development by the United States its new strategic concept called Force Projection, which was created after the Gulf War, so the decision to conduct an annual exercise under the RSOI since 1994 was made. $^{45}$

The Foal Eagle (FE) is one of the three joint South Korean and American military exercises held each year. The first group of the practice in the FE is mentioned before the Reception, Staging, Onward Movement and Integration (RSOI) and takes place around the April. And as well it was said previously, the exercises under the RSOI rely on the simulation of the movements of troops on a large scale on the Korean Peninsula. In this phase, the simulation takes into account that the war with North Korea is inevitable, but the "real fight" with the North Korean forces has not yet started. The second and third phase of those exercise is done during the above-mentioned Ulchi Focus Lens/Ulchi Freedom Guardian, where the first days of the action in the fight are trained using the computer simulation. Later, the computer simulations are continued with the participation of the real troops and the actual performance of the military exercises. ${ }^{46}$

However, the South Korean-American military cooperation is not only focused on the joint military exercises. The army of the Republic of Korea supported the U.S. Army in its intervention in Iraq. The authorities in Seoul send to Iraq in 2004, and precisely - to Irbir, the South Korean troops in the number of 3600 soldiers. ${ }^{47}$ That decision has met with the great displeasure of the South Korean public opinion; that objection was due to the intensification and the increased number of attacks on the foreign troops, ${ }^{48}$ and as

43 Military Alliance - The ROK-US Combined, op. cit.

44 Ulchi-Focus Lens, http://www.globalsecurity.org/military/ops/ulchi-focus-lens.htm (20.09.2011).

45 Military Alliance - The ROK-US Combined, op. cit.

46 US Forces Korea - Exercises, op. cit., p. 47.

47 Korea Pld./Parlament za przedlużeniem misji w Iraku, ale także za redukcja liczby żolnierzy, http://wiadomosci.gazeta.pl/Wiadomosci/1,80708,3809958.html (16.09.2011).

48 Seul wyśle swoich żolnierzy do Iraku, http://www.wprost.pl/ar/53037/Seul-wysle-swoich-zolnierzydo-Iraku/ (16.09.2011). 
well from that that the South Koreans regard that war as unjust. ${ }^{49}$ But the South Korean authorities wanted to emphasize in that way the alliance between the Republic of Korea and the United States and to gain a stronger position against North Korea. ${ }^{50}$ The sending its troops by South Korea was the first joint operation carried out by South Koreans with the U.S. forces since the Vietnam War. ${ }^{51}$ In that way the South Korean contingent was the third largest contingent - after the contingent of the United States and Great Britain. The main task of the South Korean troops was first of all the rebuilding hospitals, roads and schools. ${ }^{52}$ The mission of the Republic of Korea to Iraq ended in December 2008. It was the result of the expiry of the mandate of the United Nations for the operation on December 31, 2008; apart from South Korea, at that time 12 other states withdrew. The South Korean troops, and precisely - its medical unit, sent at the request of the United States, provided assistance for the Iraqi civilians in the number 89000 and more. Moreover, the South Korean soldiers trained in the operating computers and the other equipment nearly 2000 people. ${ }^{53}$ During that mission the only one South Korean soldier died - he committed a suicide. ${ }^{54}$ It is worth to mention that the South Korean government's mandate to stay and the South Korea's military participation in the operation in Iraq was extended four times - every time for a year and each time at the request of the United States. ${ }^{55}$

The South Korean Army is also supporting the U.S. Army in Afghanistan. The participation of the South Korean troops took place in two phases - the first phase lasted from 2002 to 2007, when it was decided to withdraw the South Korean troops and the second - since 2010, when the authorities in Seoul agreed to re-send its own soldiers to Afghanistan. In the first six-year mission of the South Korean troops the 50 rescuers and 150 engineers took part; their task was to assist in the reconstruction. The group of the engineers played an unique role in the construction of the U.S. military base in Bagram, including also the construction of the runway surface or the expansion of the major roads. While the group of 50 South Korean rescuers provided medical services to more than 259 thousands of Afghan civilians, providing medical care on average 180 Afghans per day. ${ }^{56}$ The reason for the decision to withdraw from Afghanistan the South Korean troops was the kidnapping in 2007 and taking as the hostages the twenty three

49 Korea Poludniowa kończy misję, http://www.rp.pl/artykul/55308,227353_Korea_Poludniowa konczy_misje.html (16.09.2011).

${ }^{50}$ Korea Ptd.: Ostatni żotnierze powrócili z Iraku, http://www.money.pl/archiwum/wiadomosci_agencyjne/pap/artykul/korea;pld;;ostatni;zolnierze;powrocili;z;iraku,177,0,409777.html, (16.09.2011) and J. Piasecki, Korea Poludniowa rozpoczyna wycofywanie wojsk z Iraku, http://www.psz.pl/index.php?option=com_content\&task=view\&id=15237 (16.09.2011).

${ }_{51}$ Parlament Korei Poludniowej zagłosowat za wystaniem ponad 3 tys. żotnierzy do Iraku, http://wyborcza.p1/1,75248,1912690.html (16.09.2011).

${ }_{52}$ Korea Poludniowa kończy misję, op. cit. and Korea Płd.: Ostatni żolnierze powrócili z Iraku, op. cit.

53 Korea Poludniowa kończy misję, op. cit.

54 J. Piasecki, Korea Poludniowa rozpoczyna wycofywanie wojsk z Iraku, op. cit.

55 M. Piskur, Korea Poludniowa wycofa swoje wojska z Iraku, http://www.psz.pl/tekst-13537/ Korea-Poludniowa-wycofa-swoje-wojska-z-Iraku (16.09.2011).

56 Afghanistan: Korean troops end 6-year mission in Afghanistan, http://reliefweb.int/node/ $252211(17.09 .2011)$. 
South Korean Christian missionaries. ${ }^{57}$ However the government of South Korea, despite requests from the U.S. administration for an extension of the mission of the Republic of Korea in Afghanistan, which was supposed to be completed in 2007, decided to withdraw South Korean soldiers already in July 2007 in exchange for the release of the missionaries, kidnapped by the Taliban. ${ }^{58}$ Unfortunately, the authorities in Seoul failed to save the life of all the kidnapped missionaries - two of them were killed. The withdrawal of the South Korean troops became a reality, but the South Korean government still tried to provide information to the public, that the decision to leave Afghanistan by the South Koreans was made long before and the kidnapping of missionaries did not have anything in common with the withdrawal. ${ }^{59}$ However, that withdrawal did not mean the complete abandonment the case of Afghanistan by the South Korean government, the plans to send there about 20 civilian specialists has appeared. Those specialists would help in the further reconstruction of the region. ${ }^{60}$

In 2009 the government of the Republic of Korea approved a plan to re-send to Afghanistan the South Korean soldiers, this time in the number of 320 . Their task was and still is the protection for the 100 South Korean civilians workers of the humanitarian organizations and assistants in the reconstruction of Afghanistan. In addition, South Korean government made also a decision to send to Afghanistan 40 police officers who would be helping to train the Afghan police. The duration of this plan is the time interval between July 2010 and December 2012. ${ }^{61}$ In 2010 that plan was adopted by the South Korean National Assembly, but the number of soldiers was increased to 350 . The South Korean soldiers are deployed in the province Parwan, which is located in the central part of Afghanistan. ${ }^{62}$ The American base in Bagram is close to the South Korean base, so for the South Korean troops it means the ability to easily and quickly obtain help from the American army. The sending by the Republic of Korea its troops for a period of time 2.5 years is something new in the South Korean policy, because since the deployment of its troops in Vietnam the Republic of Korea usually has sent its troops with the one year mandate. ${ }^{63}$

The another form of the closer U.S.-South Korean military cooperation has become the multinational military exercises. In February 2012 the Republic of Korea for the first time - by sending its troops to Thailand - took part in the Cobra Gold - the largest multilateral military exercises in the Asia-Pacific with the participation of the United States. In those exercises, except the United States, take part: Thailand, Indonesia, Ja-

57 D. H. Hwang, Korea's troop deployment in Afghanistan serves Korea's national interest: scholar, http://english.yonhapnews.co.kr/national/2010/01/05/91/0301000000AEN20100105000700315F.HTML (17.09.2011).

58 South Korean troops leaving Afghanistan, http://www.upi.com/Top_News/2007/11/05/ South-Korean-troops-leaving-Afghanistan/UPI-79741194266854/ (17.09.2011).

59 Korea Poludniowa ponownie wyśle żotnierzy do Afganistanu, http://www.psz.pl/tekst-28255/ Poludniowa-Korea-ponownie-wysyla-zolnierzy-do-Afganistanu (17.09.2011).

${ }^{60}$ South Korean troops leaving Afghanistan, op. cit.

61 S. K. Jung, S. Korea to Send 360 Troops, Police to Afghanistan, http://www.koreatimes.co.kr/ www/news/nation/2009/12/113 56935.html (17.09.2011).

${ }^{62}$ Korea Poludniowa ponownie wyśle żotnierzy, op. cit.

63 S. K. Jung, S. Korea to Send 360 Troops, op. cit. 
pan, Malaysia and Singapore. The Cobra Gold is an annual military drill, which is aiming at improving the cooperation between the partners and ensuring the security in the region. ${ }^{64}$

\section{THE FUTURE MILITARY COOPERATION}

Nowadays, the alliance between the Republic of Korea and the United States is trying to resist the five major issues, which can lead to the change of the structure of the South Korean-American alliance and the U.S. presence in the Republic of Korea. Among those five issues stand out: "[...] (1) the relocations of U.S. troops in South Korea and reductions in U.S. force levels; (2) the separation of the combined U.S.-South Korean (R.O.K.) military commands into two commands; (3) possible further reductions of U.S. forces in South Korea, particularly U.S. ground forces; (4) a South Korean military contribution to Afghanistan; and (5) South Korea's share of the cost of maintaining U.S. forces in South Korea (i.e., host nation support)". ${ }^{65}$

In South Korea more than 28 thousand of the U.S. soldiers are still deployed, but the Republic of Korea in its dealings seeks to the independence from the U.S. forces, partially or completely. So, since 2009 South Korea with the United States have increased the joint efforts aiming at transforming the alliance, which had already been nearly sixty years active. Initially the primary objective of the South Korean-American alliance was to provide the defense against the attack from North Korea, but now the both countries seek to change the nature and the objective of that alliance - to a regional and even a global partnership, in which partnership the United States and the Republic of Korea will work together in solving many of the problems occurring not only on the Korean Peninsula, but also outside the peninsula. Therefore, the two countries announced the formation of the Strategic Alliance 2015, the relocation plan of the U.S. troops stationed in the Republic of Korea, and also the plan of the increasing the South Korean defense capabilities. ${ }^{66}$ In accordance with the adopted jointly by the Lee Myung Bak, the president of the Republic of Korea, and Barack Obama decision, the South Korean army the full operational readiness to take the independent action will reach in December 2015. In this way, the transmission of the military sovereignty to the Republic of Korea by the American authorities and U.S. army is again delayed. The decision made in 2010 by the leaders of those two countries differs from the plans of the former President of the Republic of Korea, Roh Moo Hyun, who - as the date for achieving the full independence of the South Korean military - determined on April 2012. ${ }^{67}$ This decision was the result of the concluded in 2007 between the United States and South Ko-

\footnotetext{
${ }^{64}$ US-ROK Relations in the New Year, http://asiasociety.org/policy/strategic-challenges/usasia/ us-rok-relations-new-year (20.02.2012).

${ }^{65}$ L. A. Niksch, Korea-U.S. Relations: Issues for Congress, January 2010, http://assets.opencrs.com/ rpts/RL33567_20100112.pdf (29.09.2011), p. 16.

${ }^{66}$ M. E. Manyin, E. Chanlett-Avery, M. B. Nikitin, M. A. Taylor, U.S.-South Korea Relations, November 2010, http://fpc.state.gov/documents/organization/152040.pdf (11.09.2011).

${ }_{67}$ M. Polkowska, Armia Korei Poludniowej niezależna dopiero w 2015 roku, http://www.polska-azja.pl/2010/06/28/armia-korei-poludniowej-niezalezna-dopiero-w-2015-roku/ (24.08.2011).
} 
rea agreement on the transfer of OPCON, that is the military operational control. For the president of South Korea this agreement significantly affected the Korean sovereignty, but the Americans had seen the agreement in terms of the global requirements for the U.S. military posture in the international arena. ${ }^{68}$

It is worth to mention, that the U.S. for the first time - but only partially - wanted to withdraw from South Korea in 2004. They planned also, that in 2005 the number of the U.S. troops stationed in bases in the Republic of Korea would be 12 and a half thousand of the soldiers. But that time the authorities in Seoul came to ask the U.S. administration not to reduce the number of the American soldiers in South Korea for the next three years. Then the mentioned before agreement to withdraw the U.S. troops by 2012 was signed. It is important to add, that the U.S. authorities wanted to give control to the Republic of Korea of the army already in 2009; that was associated with the South Korean engagement in Iraq and Afghanistan. ${ }^{69}$

The change of the president in the Republic of Korea has also brought a change in South Korean-American cooperation. In 2009 the Joint Vision for an Alliance was announced, stressing the importance of South Korea-U.S. cooperation in security. In addition, it extends the scope of this cooperation in the areas, including economic and social issues, and as well the countering the regional and global challenges. The extension of this cooperation may to lead to the future institutionalization, and the alliance between the United States and South Korea would take a form of an equal and sustainable alliance. ${ }^{70}$

The plan of the actions, which will lead to the transformation of the military alliance between the Republic of Korea and the USA, was presented in the mentioned before Strategic Alliance 2015 (SA 2015). That new plan is the result of the first ever meeting of the defense ministers of those two countries, the meeting, which took place in Seoul in 2010, also known as " $2+2$ meeting". 71 The Strategic Alliance 2015 is a loose term, that by its scope not only covers, but also harmonizes various efforts leading to the transformation of the South Korean-American alliance. ${ }^{72}$ The plans contained in the SA 2015 not only include the transformation of the military operational control, when South Korea receives a possibility to lead the fight independently, but also the consolidation of the U.S. bases in the two centers. The issues concerning the extension of the stationing of U.S. troops also will be standardized. The U.S. soldiers will be stationing in South Korea for a period of 2-3 years with the possibility of coming to the Republic of Korea those soldiers with their families. The issues related to the management of the U.S. forces stationed in South Korea also will be normalized; those aspects will be adapted to wider, and thus the global mission requirements with the participation of the U.S. military. ${ }^{73}$

68 T. O, U.S.-ROK Strategic Alliance 2015, "Center for U.S.-Korea Policy. The Project of The Asia Foundation", September 2010, Vol. 2, No. 9, http://asiafoundation.org/resources/pdfs/ CUSKPNewsletter29SepWEB.pdf (11.09.2011).

69 A. Bober, Korea Poludniowa i USA, op. cit.

${ }^{70}$ T. O, U.S.-ROK Strategic Alliance 2015, op. cit.

71 Ibidem.

72 Background on the Secretary of Defense Trip to China, Japan, and the Republic of Korea, $\mathrm{http}: / /$ www.defense.gov/home/features/2011/0111_gates1/rok.aspx (20.01.2012).

73 T. O, U.S.-ROK Strategic Alliance 2015, op. cit. and US Military Facilities: Korea, http://www.globalsecurity.org/military/facility/korea-tour.htm (25.02.2012). 
The basis for SA 2015 is the plan leading to the transformation the military operational control of the U.S.-ROK Combined Forces Command in the ROK Joint Chiefs of Staff. ${ }^{74}$ While the United States Forces Korea will transform in the Unites States Korea Command or the U.S. KORCOM and it will provide the "workforce" for the ROK Joint Chiefs of Staff. However, the United States will continue to strengthen the defense of South Korea, using to that purpose the full power of the U.S. Army. ${ }^{75}$

Like it was mentioned before, originally the transformation of the military operational control was planned in 2012, but the United States decided to accept the wish of the Republic of Korea; the South Korean request concerned the delay of the implementation of the plan OPCON. That decision was made after making the strategic assessment of the security, and as well after the consideration of possible changes in the alliance, which could occur in the next $5-10$ years. ${ }^{76}$

Both the OPCON (which realization is planned in December 2015), and also the initiatives associated with that plan, may have to lead to changes in the military plans, and also in the carried out jointly by South Korean and U.S. armies exercises - they ought to be better adapted to the current and the future threats. The changes should also take place in the deployment of the U.S. forces on the Korean Peninsula, and also when the OPCON will be realized, the restructuring of the relationship between commanders will be done. Also then the American troops will consist of a command, which will support the South Korean army, while the army of the Republic of Korea will command during the fights. On the other hand, the U.S. troops in South Korea will increasingly contribute to the regional capacity-building of the Republic of Korea, support the efforts of the operations related to the isolation of sea battlefield and the missions of fighting with the piracy; those U.S. troops will also give the provision of the humanitarian aid, and as well the operation and activities of relief for South Korea in case of disasters. Moreover, the American military bases located in the Republic of Korea will be strategically placed, so in that way they will be able to immediately respond to any events that threaten the security in the region; the U.S. soldiers found in these bases will be supposed to much more effectively respond to such threats, than if it was the case involving the soldiers straight from the United States to solve the regional problems. ${ }^{77}$

Among the plans of the authorities of the Republic of Korea the one specific plan also appeared. That plan assumes that about the year 2016 the number of the U.S. installations and the equipment on the territory of South Korea will decline from 107 to 48 . It will the effect of the transformation and consolidation of the American presence in the Republic of Korea. The assumed consolidation is designed to not only reduce the area occupied by the U.S. troops, but also to increase the readiness and efficiency of these troops, and especially - to reduce the costs associated with the American presence in South Korea. ${ }^{78}$

\footnotetext{
74 Background on the Secretary of Defense, op. cit.

75 US-ROK Relations, op. cit.

${ }^{76}$ Background on the Secretary of Defense, op. cit.

77 Ibidem.

78 US-ROK Relations, op. cit.
} 
According to the Defense White Paper of Ministry of Defense of the Republic of Korea from 2010, the United States and South Korea plan to further develop their current alliance in the comprehensive strategic alliance, in which the two countries will expand their common interests and contribute to the peace in the world. Moreover, the USA and the Republic of Korea will undertake the joint efforts to strengthen their cooperation with the regional organizations, as well with the nations from this region; they also plan to promote the peace and economic development in the Asia-Pacific. ${ }^{79}$

The significant influence on the nature of the military alliance between South Korea and the United States will have the changes and developments in North Korea, the main threat to South Korea, but also to the East Asia. After the death of Kim Jong Il the North Korean authorities have stated, that they under the new leader, Kim Jong Un, would not change their policy, especially towards the Republic of Korea ${ }^{80}$ The lack of changes was seen in the case of the recently (20 February 2012) conducted military maneuvers with participation the United States and South Korea near the disputed border with the DPRK; at that time the North Korean authorities (as with any other exercises involving South Korean troops) threatened to launch "[...] a merciless retaliatory blow". ${ }^{81}$ and also stated that the DPRK "[...] is ready for a «total war» and those exercises will result in the collapse of the bilateral relations" ${ }^{, 82}$ between North Korea and the Republic of Korea.

Zbigniew Brzeziński in "The grand chessboard" has noted, that until there are two Korean states, which can turn into the outbreak of another war on the Korean Peninsula, the U.S. troops ought to, or even must, continue their presence in South Korea, because their unilateral withdrawal would inevitably accelerate the outbreak of war between the Republic of Korea and the DPRK. Moreover, the leaving the Korean Peninsula by the U.S. Army would lead to the end of the American military presence in the near Japan, which could also lead to acceleration of the process of reinforcing the Land of the Rising Sun, and thus also to destabilization in the region of Asia and Pacific. ${ }^{83}$

$* * *$

1. The sign of the acceptance by the USA a role as "a protector" of the Republic of Korea is the permanent deployment of the U.S. troops (land, sea and air forces) on South Korean territory. But the number of the stationing in the Republic of Korea American soldiers has evolved over the years, mainly in the direction tending to decrease it. For now, that number stands at 28 and a half thousand soldiers, but the situation not only on the Korean Peninsula and in the United States, but also around the

792010 Defense White Paper, http://www.mnd.go.kr/mndEng_2009/DefensePolicy/Whitepaper/index.jsp (25.02.2012), p. 79.

${ }_{80}$ R. Gopalakrisnan, North Korea's new leaders lash out at South Korea and allies, http://www.reuters.com/article/2011/12/30/us-korea-north-idUSTRE7BT04S20111230 (30.12.2011).

81 Ł. Ryniec, Napięcia na linii Seul-Pjongjang, http://www.psz.pl/tekst-41025/Napiecia-na-linii-Seul-Pjongjang (22.02.2012).

${ }^{82}$ Ibidem.

83 Z. Brzeziński, Wielka szachownica. Główne cele polityki amerykańskiej, Warszawa 1998, p. 193. 
world, will affect whether this number will remain at current level, will be reduced or the U.S. troops will completely withdraw from South Korea.

2. The another manifestation of the close alliance and the cooperation between the United States and the Republic of Korea are jointly carried out military exercises involving troops from both countries. There are several groups of those exercises, which are conducted each year, and their purpose is mostly to show North Korea that the cooperation of the American and South Korean armies is strong and consistent, and that the North Korean army, powerful in terms of the number of soldiers, does not have much chance of success against the combined forces of the United States and South Korea. The DPRK every time "nervously" responds to the joint maneuvers of the USA and the Republic of Korea, at all (repeating like a mantra), that they will meet with an armed response from the North.

3. The military cooperation between the United States and South Korea is not only concerned around the joint military exercises, it is also the support by the South Korean forces for the U.S. troops in their activities in Iraq or in Afghanistan, which support is the first for the army of the Republic of Korea since the Vietnam War. In 2012 for the first time the South Korean forces took part in the international military exercises in the region of Asia and Pacific, with participation of the United States.

4. The American military presence in the Republic of Korea is not perceived positively by the South Korean society. The anti-American sentiment mainly results from the incidents involving the U.S. soldiers, often related with breaking the South Korean law, quite often with the committing the sexual offenses and as well, purposely or not, with the killing the citizens of the Republic of Korea. For many South Korean citizens the American military presence remind them the position of the Republic of Korea in its relations with the USA as the state which is subordinate to the United States.

5. Nowadays, the alliance between the Republic of Korea and the USA is trying to adapt to the modern world, it evolves and now extends not only to cooperate in the sphere of the military, but as well in the economic and social spheres. The changes in this alliance also include the organizational issues, when in the near future the full command over its own armed forces will be transferred to South Korea. In this way the Republic of Korea strives to achieve the greater independence in the military, and to strengthen its position in its relations with the U.S. ally to be treated as an equal partner in this relationship.

\begin{abstract}
The purpose of this study is introducing the role and importance of the United States in ensuring the safety of South Korea. The USA, in act of signing the ROK-U.S. Mutual Defense Treaty with the Republic of Korea in October, 1953, has committed to safeguard the national security of South Korea, and, in particular, to provide protection against external aggression, mainly from North Korea. The strengthening of the guarantees is assisted by the American military presence in the territory of the Republic of Korea, and as well holding of joint military exercises by the U.S. and Korean Armies several times a year. The attention is also drawn to the currently U.S.-South Korean military alliance that has been evolving for years, and seeks to adapt it to the challenges and problems of the modern world, such as common missions in Iraq or Afghanistan.
\end{abstract}




\section{STANY ZJEDNOCZONE JAKO GWARANT BEZPIECZEŃSTWA KOREI POLUDNIOWEJ}

\section{STRESZCZENIE}

Celem opracowania jest ukazanie roli i znaczenia Stanów Zjednoczonych w zapewnianiu bezpieczeństwa Korei Południowej. USA, podpisując z Republiką Korei w październiku 1953 roku Układ o wzajemnej obronie, zobowiązały się do gwarantowania bezpieczeństwa narodowego Korei Południowej, a w szczególności do zapewniania ochrony przed agresją zewnętrzną, głównie ze strony Korei Północnej. Wzmocnieniu gwarancji towarzyszy amerykańska obecność wojskowa na terytorium Republiki Korei, a także odbywające się kilka razy do roku wspólne ćwiczenia wojskowe armii obu państw. Zwraca się również uwagę na to, iż obecnie amerykańsko-południowokoreański sojusz militarny ulega ewolucji, która ma na celu dostosowanie go do wyzwań i problemów współczesnego świata. 